Revista Eletrônica do Mestrado em Educação Ambiental

\title{
Educação pública como máquina de guerra: notas para um embate em curso
}

\author{
Janete Magalhães Carvalho ${ }^{1}$ \\ Universidade Federal do Espírito Santo \\ ORCID https://orcid.org/0000-0001-9906-2911 \\ Steferson Zanoni Roseiro ${ }^{2}$ \\ Universidade Federal do Espírito Santo - UFES \\ ORCID http://orcid.org/0000-0003-1424-2281
}

Resumo: Com o objetivo de apontar os enfrentamentos realizados a partir das escolas contra a máquina de guerra capitalista neoliberal, este artigo propõe discutir a educação pública como máquina de guerra insurrecional. Parte do princípio de que o capitalismo atual faz circular uma série de imagens negativas sobre a educação pública e os movimentos políticos de professores e estudantes. Para tanto, metodologicamente, a pesquisa foi realizada com professores de uma escola de ensino fundamental, em dois momentos: pesquisa pelos professores de imagens na Internet sobre os movimentos de maio de 2019; e estabelecimento de redes de conversações nas quais os professores problematizaram o campo de forças que atravessa o plano de imanência do cotidiano das escolas públicas no Brasil atual.

Palavras-chave: Educação pública. Imagens de resistência. Máquina de guerra.

\section{La educación pública como máquina de guerra: notas para una lucha en curso}

Resumen: Com el objetivo de señalar los enfrentamentos realizados por las escuelas contra la maquina de guerra capitalista neoliberal, este artículo propone discutir la educación pública como una maquina de guerra insurreccional. Parte del princípio que el capitasmo actual hace circular una serie de imágenes negativas sobre la educación pública y los movimentos políticos de maestros y estudiantes. Con este fin, metodológicamente, la investigación, se realizo con maestros de una escuela primaria, en dos momentos: investigación realizada por maestros de imágenes en Internet sobre los movimientos de mayo de 2019; y el establecimiento de redes de conversaciones en las cuales los maestros problematizaron el campo de fuerzas que cruces el plan de inmanencia en todos los dias de las escuelas públicas en Brasil hoy.

\footnotetext{
${ }^{1}$ Doutora em Educação; professora do Programa de Pós-Graduação em Educação da universidade Federal do Espírito Santo (PPGE/UFES). e-mail: dinno_sauro@ hotmail.com

2 Doutorando em Educação do Programa de Pós-Graduação em Educação da Universidade Federal do Espírito Santo (PPGE/UFES). e-mail: dinno sauro@ @otmail.com
}

Rev. Eletrônica Mestr. Educ. Ambient. Rio Grande, Dossiê temático "Imagens: resistências e criações cotidianas", p. 127-151, jun. 2020. E-ISSN 1517-1256 
Palabras clave: Educación pública. Imágenes de resistência. Maquina de guerra

\title{
Public education as a warmachine: notes for anon going debate
}

\begin{abstract}
In order to point to the confrontations carried out bythe schools against the neoliberal capitalist warmachine, this article proposes to discuss public education as aninsurrectionary warmachine. It considers that in the current capitalist system circulates a series of negative images about public education and the political movements of teachers and students. Methodologically, there search was carried out, with teachers from anelementary school, in two moments: search for teachers, on the Internet, for images about the movements of May 2019; conducting conversation networks in which teachers problematized the field of forces that runs through the plane of immanence in the daily life of public schools in Brazil today.
\end{abstract}

Key words: Public education. Resistance images. War machine.

\section{9, um marco}

Para todos na educação, o ano de 2019 foi um marco aparentemente sem volta. Vimos ruir algumas das poucas conquistas que ainda perduravam. As ameaças e as difamações iniciadas em período eleitoral em 2018 foram intensificadas. Parecíamos, aos olhos dos governos, uma quadrilha organizada. Inclusive, fomos acusados de algo parecido pelo presidente eleito.

Todavia, apesar das ofensas, dos ultrajes e da multiplicação de asco, foi também um momento de tomada radical de nossa importância para enfrentar as políticas de esfacelamento da educação pública. Foi graças aos ataques hediondos sofridos por nós em 2019 que voltamos a nos dar conta de que somos demasiadamente necessários e de força sem igual.

Então, 2019 foi um marco para os ataques contra nós, professoras e professores, mas também foi o momento de aprendermos a procurar, mesmo entre aqueles que tentávamos nos diferir, possibilidades de conluio. Não nos renderíamos facilmente.

O ano de 2020 chegou e não comemoramos uma única vitória. Iniciamos, desde o ano passado, um processo de luta que não nos permite comemorar nada até que as condições mínimas de existência escolar sejam recuperadas. A educação pública pode parecer estar acamada em um corredor de hospital público. Talvez esteja. Decerto, entretanto, está fazendo novos arranjos, novos aliados, produzindo novas redes do comum para que possa se colocar em condição de enfrentamento contra a máquina de guerra do capital novamente.

Rev. Eletrônica Mestr. Educ. Ambient. Rio Grande, Dossiê temático "Imagens: resistências e criações cotidianas", p. 127-151, jun. 2020. E-ISSN 1517-1256 
Eis o propósito desta escrita: evidenciar as lutas da educação pública contra o capital, seja nas ruas como nos atos conhecidos como $15 \mathrm{M}$ e $30 \mathrm{M},{ }^{3}$ seja no interior das escolas que a todo o momento se recusam a se tornarem apáticas à vida.

A partir do conceito de máquina de guerra de Gilles Deleuze e Félix Guattari e de imagem em Henri Bergson, apostamos nas condições de luta de professoras e professores espalhados na educação pública brasileira. Há, sim, um campo de batalha que parece demasiado injusto para nós; todavia, guerreiros que somos, não cedemos um único centímetro. Continuamos em guerra, arranjando parcerias e alianças em todos os lugares em que circulamos.

Com certeza, 2019 foi um marco das políticas nefastas que já vinham se engatinhando e sendo engatilhadas há muito mais tempo que nossa história permite contar. Esse terceiro decênio do século XXI, contudo, será lembrado como o início da derrota da maquinaria fascista, racista, machista etc. É preciso que acreditemos nisso.

Por isso lutamos.

\section{Máquina de guerra capitalista}

Vivemos hoje numa época de grande complexidade em relação às formas de produção de subjetividade. Se cada sociedade tem seus tipos de máquinas, é porque elas são o correlato de expressões socais capazes de lhes fazer nascer e delas se servir como verdadeiros órgãos da realidade nascente.

Segundo Lazaratto (2014), o espaço público está saturado com a circulação de signos, imagens e palavras e com a proliferação de dispositivos de sujeição que, ao encorajar e solicitar que falem e se expressem, impedem a enunciação singular e neutralizam processos heterogêneos de subjetivação. Para que uma enunciação, uma fala singular seja possível, deve-se deixar "[...] a infinita tagarelice do consenso midiático, forçar rupturas no espaço público" (p. 125). Do mesmo modo, para poder "ver", devemos nos retirar do incessante bombardeio de clichês visuais. Para existir politicamente, para

\footnotetext{
${ }^{3}$ Movimento ocorrido em maio de 2019, convocado pelas Associações de Docentes e Estudantes e porEntidades Sindicais contra: os sucessivos cortes nas políticas educacionais (ensino superior e educação básica) e a ameaça de acabar com a vinculação constitucional que assegura recursos para a educação (Fundeb e outras políticas); o patrulhamento ideológico nas universidades e a ofensiva da Lei da Mordaça (Escola sem Partido); o viés privatista e sectário que fomenta as políticas educacionais; a agressão à gestão democrática e à autonomia das escolas; a inoperância inescrupulosa do Ministério da Educação, que afeta a qualidade do atendimento público nas escolas, institutos federais e universidades; a revogação de inúmeros Conselhos de acompanhamento social, impondo retrocessos à gestão democrática, dentre outros pontos de pauta.
}

Rev. Eletrônica Mestr. Educ. Ambient. Rio Grande, Dossiê temático "Imagens: resistências e criações cotidianas", p. 127-151, jun. 2020. E-ISSN 1517-1256 
simplesmente existir, mais que integrarmos o mundo comum, devemos singularizá-lo, isto é, "[...] devemos impor uma singularidade, a divisão e a diferença não estão dadas de antemão: elas têm que ser inventadas, construídas” (LAZARATTO, 2014, p. 125).

Embora o senso comum tenha o hábito de pensar a máquina de guerra somente como um subproduto do aparelho de Estado, Deleuze e Guattari (1997, p. 12) enfatizam a diferença radical de natureza entre esses dois polos e anunciam que "[...] a máquina de guerra é exterior ao aparelho de Estado". Para os autores, máquina de guerra não se refere ao aparato militar que um Estado é capaz de construir para fazer guerra contra seus inimigosinternos ou externos, pois uma máquina de guerra é sempre exterior às diversas formas de Estado surgidas ao longo da história.

A tese da exterioridade ${ }^{4}$ da máquina de guerra significa, ao mesmo tempo, que não se concebe o Estado sem uma relação com um fora de que ele se apropria sem poder reduzi-lo (a máquina de guerra institucionalizada como exército, por exemplo). Nesse entendimento, a máquina de guerra se relaciona, de direito, positivamente, com um agenciamento social que, por natureza, nunca se fecha sobre uma forma de interioridade. Logo, não há dicotomia entre máquina de guerra e aparelho de Estado e, sim, tensões, atrações, aproximações e rupturas.

Assim, haveria a máquina de guerra aliada ao aparelho de Estado e, segundo Lazzarato (2019), mais ao capital financeiro que propriamente ao Estado, portanto interior ao Estado que se manifestaria pela defesa dos interesses do capital, assim como máquinas de guerra exteriores ao aparelho de Estado relacionadas com movimentos de resistência dos grupos colonizados/subjugados pelo capital.

Para Lazzarato (2019), no confronto entre os "inimigos" políticos do século XX, o vencedor foi o capital que transformou os vencidos em "governados", acirrando a guerra entre governantes/governados por outros meios. "Porque, de fato, a guerra contra os mais frágeis nunca parou. Arrefeceu [...] mas nunca parou. Desta vez a perversão é que, até agora, o projeto autoritário vem se estabelecendo com as roupagens da democracia" (BRUM, 2018, p. 1).

No Brasil, esse movimento se manifesta pela privatização na oferta de serviços e pela retirada da demanda social de sua dimensão política coletiva, dentre elas, o direito à educação pública, o que, na perspectiva dos postulados neoliberais, implica um Estado

\footnotetext{
4‘Não basta afirmar que a máquina é exterior ao aparelho, é preciso chegar a pensar na máquina de guerra como sendo ela mesma uma pura forma de exterioridade, ao passo que o aparelho de Estado constitui a forma de interioridade que tomamos habitualmente por modelo, ou segunda a qual temos o hábito de pensar" (DELEUZE; GUATTARI, 1997, p. 1516).
}

Rev. Eletrônica Mestr. Educ. Ambient. Rio Grande, Dossiê temático "Imagens: resistências e criações cotidianas", p. 127-151, jun. 2020. E-ISSN 1517-1256 
forte para uma economia livre e/ou um Estado forte para os fracos e fraco para os fortes (os proprietários), fundamentado, em especial, na distribuição pelo crédito e, consequentemente, na proliferação de indivíduos isolados, desconectados, endividados e escravizados.

O controle das populações pela escravidão tem sido praticado, através dos tempos, por meio de técnicas de poder exercidas entre a vida e a morte, desenvolvidas bem antes do desdobramento do biopoder europeu e de sua realização total na Alemanha nazista. "A pesada máquina do colonialismo, desde sempre, mantém entre a vidae a morte - sempre mais perto da morte que da vida - aqueles que são obrigados a movê-la" (SARTRE, 1968, p. 54).

A privatização vem transformando as políticas de segurança contra os riscos sociais em dispositivos que produzem desigualdades crescentes. Foucault (2008) considera os mecanismos de privatização como dispositivos do biopoder que anulam os "direitos" sociais coletivos e individuais. Desse modo, o acesso à educação, à saúde à aposentadoria etc. dependerá da propriedade e do patrimônio, não de um direito.

Para Lazzarato (2019), o que define o capitalismo é a exploração da força de trabalho que, porém, com a intensificação das técnicas da logística, se torna uma máquina produtiva, tecnológica, informacional, administrativa e militar-policial. O capital situa-se, então, entre a exploração do trabalho altamente qualificado (tecnologia, ciência) e a exploração do trabalho servil, situando-se o trabalho no setor educação entre os dois. Assim, questionamos: onde termina e qual a finalidade da produção da esfera do campo educacional, considerando a perda de poder diante da máquina de guerra capitalista? Haveria espaço para a resistência, visto que a máquina de guerra do capital encontra seu inimigo quando, pela luta revolucionária, as leis da produção e da governamentabilidade são contrariadas?

Para Deleuze e Guattari (1997), a própria atividade de pensar implica a existência de uma máquina de guerra. O movimento de colocar o pensamento em relação imediata com o fora, com as forças do fora, significa fazer do pensamento uma máquina de guerra, diferente do modelo gerado pelo Estado e/ou pelo capital.

Lembramos, então, que o poder e a guerra são intrínsecos um ao outro e, no capitalismo neoliberal, a guerra não passa de um componente da máquina do capital. Lazzarato (2019) argumenta que Foucault fez da biopolítica um dispositivo fundamentalmente centrado no aumento da esperança de vida, técnica de controle que perdeu o caráter negativo de repressão e se definiu como uma força positiva de produção 
dos sujeitos, da liberdade, da segurança, ou seja, definindo as técnicas de poder como produtivas. Entretanto, no século XX e no início do século XXI, as "reformas" do neoliberalismo mundial e nacional e suas guerras manifestaram o caráter negativo, destrutivo e repressivo do poder em sua face fascista: o racismo, o sexismo, o nacionalismo estreito etc.

As implicações mais visíveis se manifestam pelo exercício de um poder que não se resume a exercer uma ação sobre outra ação, envolvendo também a possibilidade de imposição davontade pela força, pela violência, por uma ação que, em vez de agir sobre outra ação, age diretamente sobre a pessoa, as populações e sobre as coisas.

Lazzarato $(2019$, p. 86) argumenta que as duas fórmulas de Foucault para descrever o poder soberano e a biopolítica - "fazer morrer e deixar viver" e "fazer viver e deixar morrer” - não se sucedem e sim coexistem, “[...] já que o fazer morrer [os despossuídos] é praticado pelos mesmos que organizam o 'deixar viver' (seria mais exato dizer 'deixar sobreviver')".

Nesse sentido, a vida em jogo não é a vida biológica da população, mas a vida política da máquina capitalista e das elites. A salvaguarda das elites envolve, necessariamente, colocar em perigo a vida das populações. Pela vida das elites e sua reprodução, a máquina de guerra capitalista está disposta a sacrificar, sem escrúpulo, a saúde, a formação/educação, a moradia etc. de várias camadas da população, ou seja, sacrificar a vida das camadas populares e da classe média baixa numa relação de força permanente ao mínimo e, então, ao invés de reduzir as desigualdades,ela as aumenta (LAZZARATO, 2019).

\section{Máquina de guerra além da reprodução em movimentos pós-coloniais}

Como o poder é constituído por uma pluralidade/multiplicidade de relações de forças e estratégias, ao mesmo tempo locais e instáveis, ele é reproduzido e produzido a cada instante. Assim sendo, se a política e a guerra, como o direito e o Estado, são estratégias interprenetradas sob a "hegemonia" da máquina do capital, elas estão sempre à disposição do poder. Entretanto, também podem ser mobilizadas para a revolução e a resistência.

As rupturas revolucionárias e as multiplicidades das relações de força encontram a maneira de se exprimir, de se problematizar, de se subjetivar de modo radical contra a máquina de guerra capitalística e suas estratégias, possibilitando a abertura dos possíveis.

Rev. Eletrônica Mestr. Educ. Ambient. Rio Grande, Dossiê temático "Imagens: resistências e criações cotidianas", p. 127-151, jun. 2020. E-ISSN 1517-1256 
Desse modo, o poder deve ser analisado a partir de suas estratégias próprias, sempre singulares, com caráter de acontecimento, imprevisíveis, que não seguem nenhuma regularidade. Daí a opção de Lazzarato (2019, p. 108) em abandonar a definição genérica de "máquina social", que produziria de maneira impessoal as normas, as leis e adotar o conceito de Deleuze e Guattari (1997) de "máquina de guerra", que implica relações entre forças a partir das quais se produzem as articulações entre a macropolítica e a micropolítica, tanto na perspectiva do capital, quanto na perspectiva da insurreição.

As máquinas técnicas, como o algoritmo, a inteligência artificial, o bitcoin, o capitalismo cognitivo, a informática e, nela, a Internet, têm estado em análise crítica constante, entretanto, falta "[...] uma teoria de sua relação com a revolução" (LAZZARATO, 2019, p. 119), ou seja, a análise da funçãodo dispositivo técnico Internet e seus meios (Instagram, Whatsapp, Facebook etc.). Neles encontramos os possíveis da proliferação de imagens que podem fazer emergir a força da máquina de guerra insurrecional como parte integrante das lutas dos colonizados.

Fanon (2011), analisando a potência revolucionária do rádio, demonstrou que a aparição de um dispositivo tecnológico, sua penetração, sua difusão e aceitabilidade dependem sempre de uma máquina de guerra.

O potencial da Internet, como dispositivo tecnológico, para além dos textos vinculados, transportam imagens e veiculam movimentos de novos sujeitos políticos (os colonizados, as mulheres, os professores e estudantes etc.) que trazem consigo novas modalidades de manifestação insurrecional. Nesse sentido, o sujeito imprevisto implica um ato imprevisto, uma ruptura que cria os possíveis de sua própria liberação.

Logo, a recepção ou recusa das informações, sua aceitação ou rejeição remetem à presença ou ausência de um corpo social, visto que a recusa e/ou a aceitação não são faculdades espontâneas de indivíduos, pois são constituídas social e politicamente.

O corpo, para Bergson (2006), funciona como um centro de captação de outras imagens por meio dos sentidos, ou seja, imagens visuais, olfativas, gustativas, sonoras ou táteis, ligadas entre si por conexões estabelecidas por meio de fluxos de energias/vibrações em redes. A memória mora no corpo e, em certo sentido, é o próprio corpo, como morada das imagens, que é capaz de sentir o mundo.

As imagens são armazenadas, segundo Bergson (2006), recebidas e alteradas por diferentes sistemas neurais que constituem dispositivos sensório-motores que, ao receberem as sensações, as memorizam. Essearmazenamento permite que sejam realizadas algumas ações de forma automática. Com a repetição, elas produzirão um processo de 
fixação de uma imagem como imagem-lembrança que possibilitará, por sua vez, a realização de ações rotineiras, conduzindo, assim, a um tipo de imagem que Bergson denominará de imagem-ação, solicitada quando uma situação semelhante ocorrer - como o vestir-se pela manhã e dirigir-se ao trabalho.

Desse modo, as imagens que chegam do exterior formarão uma das bases da memória. São as chamadas imagens-percepção (BERGSON, 2006). Essas imagens não conseguem absorver tudo que nos cercam e, portanto, operam selecionando alguns aspectos e excluindo outros. Possivelmente, essas diferenças ocorram devido a certa intensidade, necessidade e motivação já instaladas em cada pessoa pela própria massa química energética que compõe o corpo/cérebro/sistema neural. Porém, algumas imagens sofrem alterações de ordem subjetiva e, de certa forma, respondem por meio de imagensafecção que possuem, de acordo com Bergson (2006), um sentido inverso - de dentro para fora.

Podemos, então, dizer que o pensamento, como morada e fábrica de imagens, é um fenômeno múltiplo no qual diversas forças atuam umas sobre as outras formando um "campo de energia". Sendo assim, a imagem, antes que prisioneira, pode ser um vento sem fronteiras, nômade - sempre de passagem, viajante (REALI, 2017). Assim, mesmo datada e/ou referente a uma cultura, pode manter-se circulando indefinidamentecom sua capacidade de afetar e ser afetada, de modo que uma imagem, "[...] quando viaja pelo mundo, provoca a estranha sensação de que somos nós que viajamos" (p. 42).

Uma imagem pode, sendo assim, desencadear um bloco de intensidades com potência para propiciar, conforme sugeria Deleuze e Guattari (1996, p. 19), o agenciamento do desejo, “[...] deslocando-o no tempo, desterritorializando-o, fazendo proliferar suas conexões, fazendo-o passar em outras intensidades".

Justamente assim, portanto, é que nos colocamos com professoras e professores de uma escola de ensino fundamental da rede de Cariacica/ES, para tanto discutir sobre as nossas possibilidades de enfrentamento aos ataques da maquinaria capital, quanto para pensar nas imagens que fazíamos dessas nossas resistências. Com o objetivo de apontar os enfrentamentos realizados a partir das escolas contra a máquina de guerra capitalística, colocamo-nos em dois processos de pesquisa com os docentes da instituição.

Em um primeiro momento, procuramos discutir imagens de movimentos de resistência ocorridos no mês de maio de 2019, movimentos, inclusive, que contaram com a participação de sete docentes da escola. Em uma segunda etapa, após a partilha de fotografias, de leituras de faixas e cartazes das manifestações espalhados na Internet, 
começamos a conversar sobre as próprias práticas de liberdade possíveis dentro de uma escola. Trabalhando a partir de redes de conversações com professoras e professores, ${ }^{5}$ entre os meses de setembro e novembro, 20 professores se envolveram ativamente na rede e, como não poderia deixar de ser, exercitaram seus tons insurrecionais para falar da escola pública como uma máquina de guerra contra o capital.

Com efeito, como destacou uma professora, o resultado foi pensar o próprio ano de 2019 e a frente que os corpos docentes - apoiados pelos discentes - tomaram ao movimentar as ruas contra os cortes, contingenciamentos e ameaças contra a educação pública:

- Têm vezes que esse povo acha que a gente é tudo um bando de formiguinha tonta, sabe? Ameaçam nossa aposentadoria, ameaçam o Fundeb, dizem que vão acabar com as universidades públicas e ainda acham que a gente vai ficar parado?

- A merda agora já tá feita! E depois ainda falam que é a gente que doutrina os meninos pra irem pras ruas com a gente! É deles mesmos que tudo está sendo retirado! A gente não precisa doutrinar ninguém! Eles mesmos se irritam e se manifestam...

- Eu fiz questão de mostrar pras famílias dos meus alunos que eu não vim, porque fui lutar pelos direitos deles, meus, nossos... tudo em foto!

- Eu tive mais curtidas nas fotos vindas das famílias daqui da escola que dos meus próprios familiares!

Reali (2017), apoiando-se em Samain, escreve que somos condicionados tanto pela nossa forma de ver como pela peculiaridade com que as imagens olham para nós, pois imagens existem, vivem e fazem viver. Afirmando que as imagens nos fazem pensar e nos movem em diversas direções, Reali (2017, p. 59 a 61) aponta três proposições: a) "Toda imagem nos oferece algo para pensar", possuindo, portanto, força capaz de produzir movimento do pensamento; b) "Toda imagem é portadora de um pensamento, isto é, veicula pensamentos", para além da representação de objetos, faz circular criações de quem a produz e de quem, ao vê-la, a recria. Ou seja, a imagem comporta tanto seu criador como sua recriação por quem a olha; c) A imagem é "uma forma que pensa", pois as imagens são formas que, entre si, se comunicam e dialogam independentemente de seus autores.

\footnotetext{
${ }^{5}$ Ao longo do artigo, por uma questão ética e estética de escrita, apostamos na apresentação das falas produzidas durante a pesquisa em parágrafos únicos (quando muito longos) e/ou junto ao texto, em itálico, fonte 12 e com espaçamento entrelinhas simples. Foram selecionadas poucas falas (assim como poucas imagens capturadas na Internet), devido à dimensão do artigo. Optamos por não fazer o recuo típico das citações, por apostarmos na força política das próprias falas. Ao mesmo tempo, por uma questão de trato com as falas, decidimos também não fazer nenhum tipo de identificação, real ou fictícia. Acreditamos, assim, na possibilidade de falas intercambiáveis entre os corpos que vivificam as escolas.
}

Rev. Eletrônica Mestr. Educ. Ambient. Rio Grande, Dossiê temático "Imagens: resistências e criações cotidianas", p. 127-151, jun. 2020. E-ISSN 1517-1256 
Desse modo, as imagens, constituídas de potências objetivas (de fora), podem sofrer alterações profundas nas formas subjetivas (de dentro), conferindo singularidades, que, compartilhadas, podem influir nos modos coletivos de ver e sentir o mundo. As imagens põem o pensamento para funcionar e podem fazê-lo estremecer.

Deleuze (1997) distingue entre as revoluções e o devir-revolucionário; Lazzarato (2019), por sua vez, problematiza o impasse da dissociação entre a revolução e o devirrevolucionário, visto que os mundos da igualdade dos movimentos políticos e o da desigualdade capitalista reverberam movimentos diferenciais entre si. "O mundo da desigualdade, indissociável do exercício da força, arruinou sistematicamente o mundo da igualdade, reduzindo os espaços da 'secessão'[...] a quase nada. A desigualdade transpôs outro limiar no exercício de sua força com os novos fascismos" (LAZZARATO, 2019, p. 200).

Entretanto, acreditamos que a presença de um devir-problematizante ameaça tudo aquilo que é da ordem do saber como conquista ou posse. Enquanto o aparelho de Estado limita o elemento-problema para subordiná-lo a um teorema com suas proposições demonstráveis, a máquina de guerra é o paradigma da experimentação. Para Samain (2012, p. 154), “[...] todo conhecimento é 'afetivo', no sentido em que as figuras que emergem só têm valor em função do que as afeta. Cada figura designa, portanto, um acontecimento e não uma essência".

Assim, indagamos: quais enfrentamentos são possíveis contra a máquina de guerra do capital a partir das escolas? De que modos nós, na educação, nos afetamos com as imagens que circulam sobre a educação? Como vemos as imagens de resistência contra o maquinário capitalístico? E, ao mesmo tempo, quais imagens de insurreições fazemos proliferar em nossas relações?

A máquina de guerra capitalista pretende a um universal, promove um ideal de sedentarização e se dirige mais aos componentes voláteis do que aos componentes nômades. Para Deleuze e Guattari (1997), uma das tarefas fundamentais da máquina de guerra capitalista é estriar o espaço sobre o qual reina, ou utilizar os espaços lisos como um meio de comunicação a serviço de um espaço estriado, visto que não só é vital vencer o nomadismo, mas também controlar as migrações. Sempre que possível,a máquina de guerra capitalista empreende um processo de captura sobre fluxos de populações, de mercadorias, de dinheiro ou de capitais etc. "Mas são necessários trajetos fixos, com direções bem determinadas, que limitem a velocidade, que regulem as circulações, que 
relativizem o movimento, que mensurem nos seus detalhes os movimentos relativos dos sujeitos e dos objetos" (DELEUZE; GUATTARI, 1997, p. 60).

Para um movimentode máquina de guerra nômade, a questão se coloca de modo outro: o lugar não está delimitado; portanto o absoluto não aparece num lugar, mas se confunde com o lugar não limitado; o acoplamento dos dois, do lugar e do absoluto, não consiste numa globalização ou numa universalização centradas, orientadas, mas numa sucessão infinita de operações locais.

Assim, poderíamos pensar em movimentos na educação como máquina de guerra nômade que implica um vetor de desterritorialização? Em meio às linhas estriadas, aos pontos fixos, haveria a possibilidade de variações de orientação e direção que engendram movimentos rizomáticos, temporários e móveis, determinando mudanças de orientação dos percursos?

Quando os movimentos pela educação pública se constituem em máquina de guerra, mobilizam e liberam uma carga de nomadismo ou de desterritorialização, "[...] duplicam o migrante como um nômade que o acompanha, ou com um nômade potencial que ele está em vias de tornar-se, para além de uma forma-Estado" (DELEUZE; GUATTARI, 1997, p. 59). Implicamuma variabilidade das direções, de pensamentos cambiantes.

A defesa da educação pública, como máquina de guerra, mobiliza e libera uma carga de nomadismo ou de desterritorialização absoluta, duplica o migrante com um nômade que o acompanha, ou com um nômade potencial que ele está em vias de tornar-se; enfim, volta-se contra a forma-sujeição/servidão em direção a modos de liberdade (FOUCAULT, 1985) como ato de afirmação da existência do ato educativo.

\section{Declaração: estamos em guerra}

Estamos em guerra e, para muitos, essa guerra é inexistente. Somos professoras e professores em escolas públicas de todo o país e presenciamos, continuamente, descasos infinitos com tudo o que a educação pública deveria representar. Estamos em guerra contra as políticas de um governo que, depois de sucatear todos os investimentos, ainda arranja espaço em sua agenda para desmoralizar professoras e professores, alunas e alunos. Estamos em guerra com algumas famílias que, diante dos ataques midiáticos, passam a enxergar nas escolas exatamente aquilo em que a política de desmoralização tanto investe. Estamos em guerra com alunas e alunos porque, há eras, tentamos afirmar o trabalho 
educativo em apenas um dos lados da equação e nos esquecemos do conluio que vivemos. Estamos em guerra com nós mesmos porque, apesar dos ataques que nos são dirigidos, ainda não aprendemos a nos aliarmos, ainda preferimos ver divergências de práticas, teóricas ou de experiências, como limite inultrapassável.

Estamos em guerra e, em absoluto, isso não é para ser lido com lástima. Ao contrário! No momento em que cada um de nós - professoras, professores, alunos, familiares - nos dermos conta de nossa realidade guerreira, estaremos, enfim, em pé de igualdade com a cruel realidade política, porque a política em voga - neoliberalismo como estratégia da máquina de guerra capital (LAZZARATO, 2019) - não teme em jogar-nos uns contra os outros. Essa política enxerga muito além da aparente paz que reina no mundo. Na verdade, essa paz forjada é sua arma central para garantir as formas de dominação. Paz que, quando ameaçada, permite o funcionamento de formas variadas de extermínio e subjugação.

Desde a vitória apavorante do então presidente, Jair Messias Bolsonaro, durante o segundo turno das eleições de 2018, professoras e professores de todo o país foram colocadas sob alerta. À época, uma deputada do Partido Social Liberal (PSL) "preparava" seus seguidores do Twitter para gravar as aulas ministradas um dia após as eleições, visto que, segundo ela, aquele seria o momento de doutrinação mais importante $(G 1,2018)$. Momento esse que, obviamente, deveria funcionar como um desmonte da educação "esquerdista", termo usado largamente pela direita conservadora aliada à família Bolsonaro.Porém, de lá para cá, a situação tem desandado drasticamente.

Durante sua estada nos Estados Unidos, ao ser questionado sobre as manifestações docentes e estudantis realizadas nos dias 15 e 30 de maio de 2019, Jair Bolsonaro chamou estudantes do país de "idiotas úteis" e comparou professores universitários com integrantes do crime organizado. Como se não bastasse ridicularizar as manifestações, o governo também não se propôs sentar para discutir nenhuma das pautas levantadas. As universidades federais passaram todas por uma contenção de gastos tremenda, mas, no fim do ano, as verbas foram "devolvidas" às Reitorias com a urgência de serem gastas. Para que não deixemos dúvidas, essa "devolução" ocorreu apenas após a aprovação da reforma da previdência.

Entretanto, e como frisado, acreditamos que as imagens destacadas a seguir falam e nos fazem pensar sobre os possíveis... 
Foto - Convocações para as manifestações pela educação nos dias 15 e 30 de maio de 2020

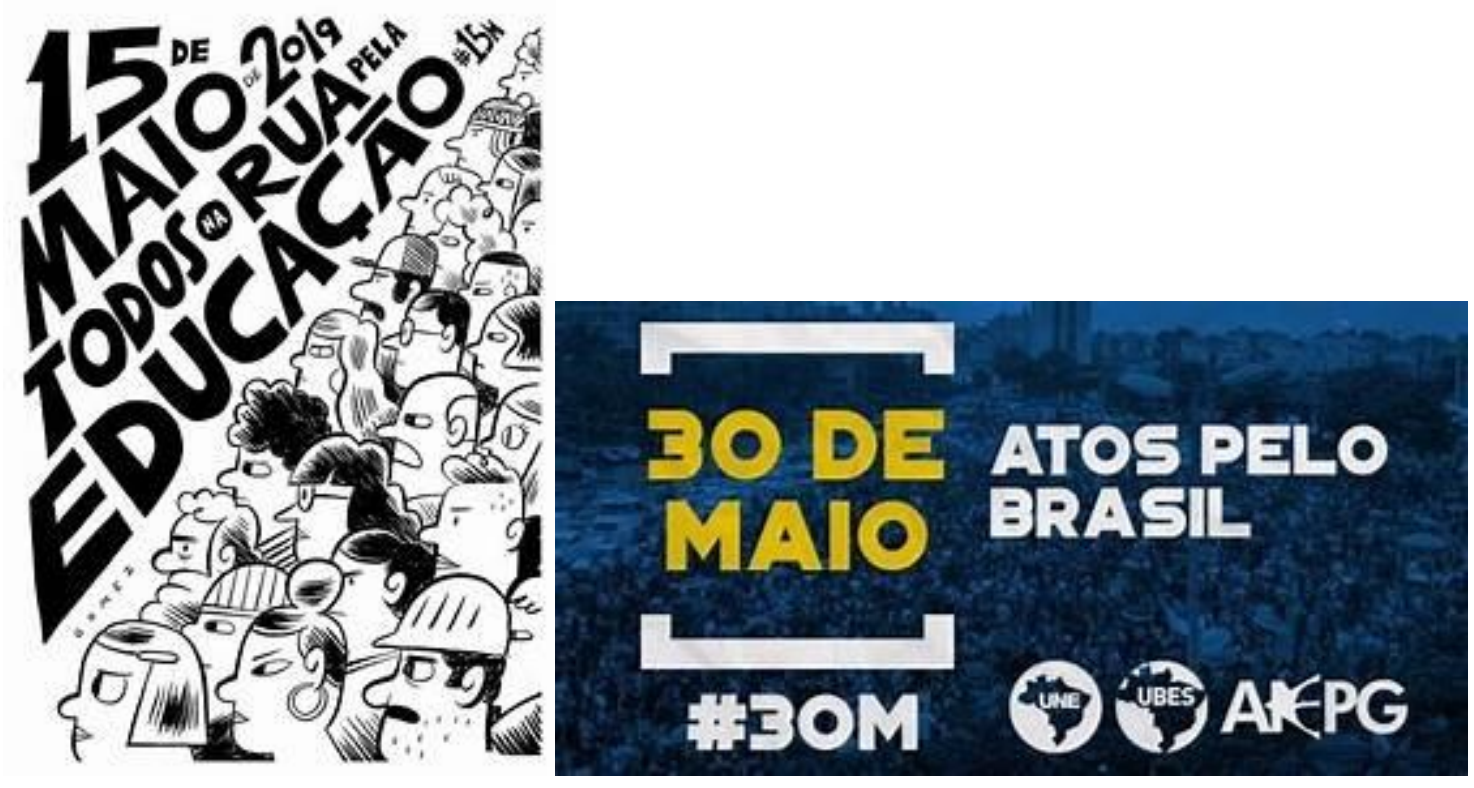

Fonte: facebook.com/events/800007443715064

A esse chamado professores e estudantes responderam com presteza:

Foto - Estudantes e professores protestam contra cortes na educação

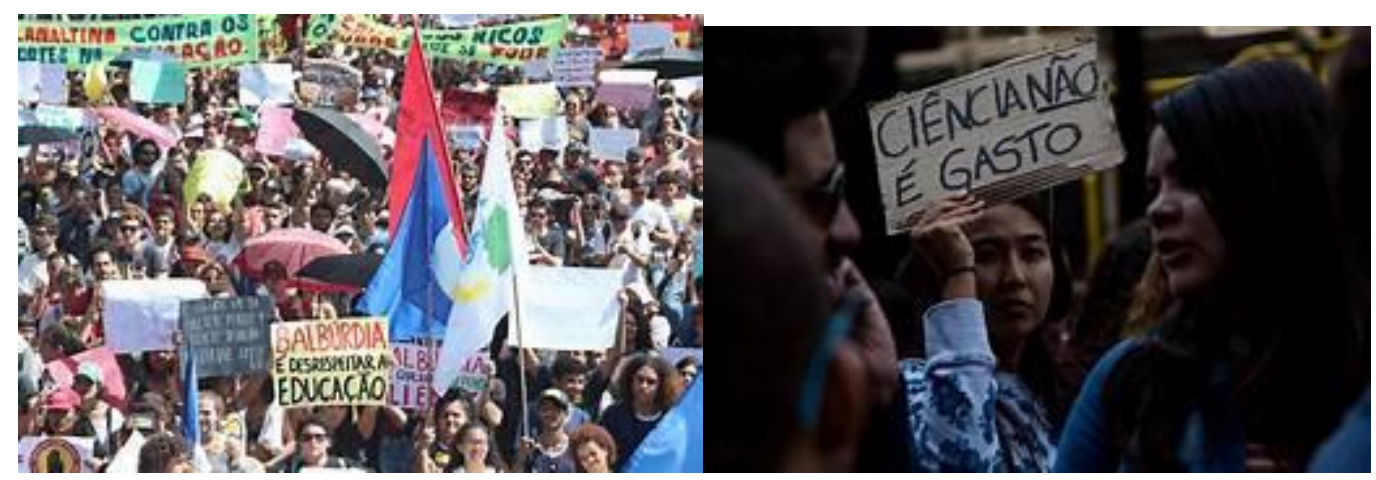

Fonte: https://veja.abril.com.br/politica/ao-vivo-estudantes-e-professoresprotestam-contra-cortes-na-educacao/

As placas nas ruas não eram poucas, mas, de modo bem estratégico, a grande máquina de guerra capitalística angariou formas de policiamento que se efetivaram nas escolas, nas casas, nas mídias e mesmo pelas ruas. Em pouco tempo, professoras e professores foram colocados contra as paredes de modo a sermos vigiados tanto por nossos trabalhos, quanto por nossas preocupações.

Não poderíamos esperar menos de um governo que articulou tão sabiamente o WhatsApp e a rede intrincada de fake news para se eleger e derrubar todos os possíveis 
candidatos. A tríplice aliança capital-política-tecnologia não apenas é encarnada por Trump, não somente ele éum novo tipo de fascista e racista constituído de partes orgânicas e cibernéticas (LAZZARATO, 2019). Jair Messias Bolsonaro e sua trupe seguiram a receita à risca e adicionaram alguns pontos próprios para que ganhassem a eleição. $\mathrm{O}$ resultado é exatamente o de uma aliança maligna na qual o presidente eleito existe quase unicamente via Twitter e suas lives de Facebook que se repercutem via WhatsApp. A figura física do presidente é radicalmente desnecessária. Ele existe como imagem viralizada. Ou, fazendo certas alterações na leitura de Peter PálPelbart (2019), a política à moda Bolsonaro é uma política de joystick, em que os players (operadores) fazem/testam o cenário brasileiro com vários game overs e torcem para ter infinita continuidade.

No governo Bolsonaro, foi a figura do trabalhador que se tornou o personagem do jogo em beta test da política empresarial-militar vigente. Aparentemente, o professor se tornou um dos personagens mais populares.

Foto - Professores e alunos em manifestação contra cortes na educação
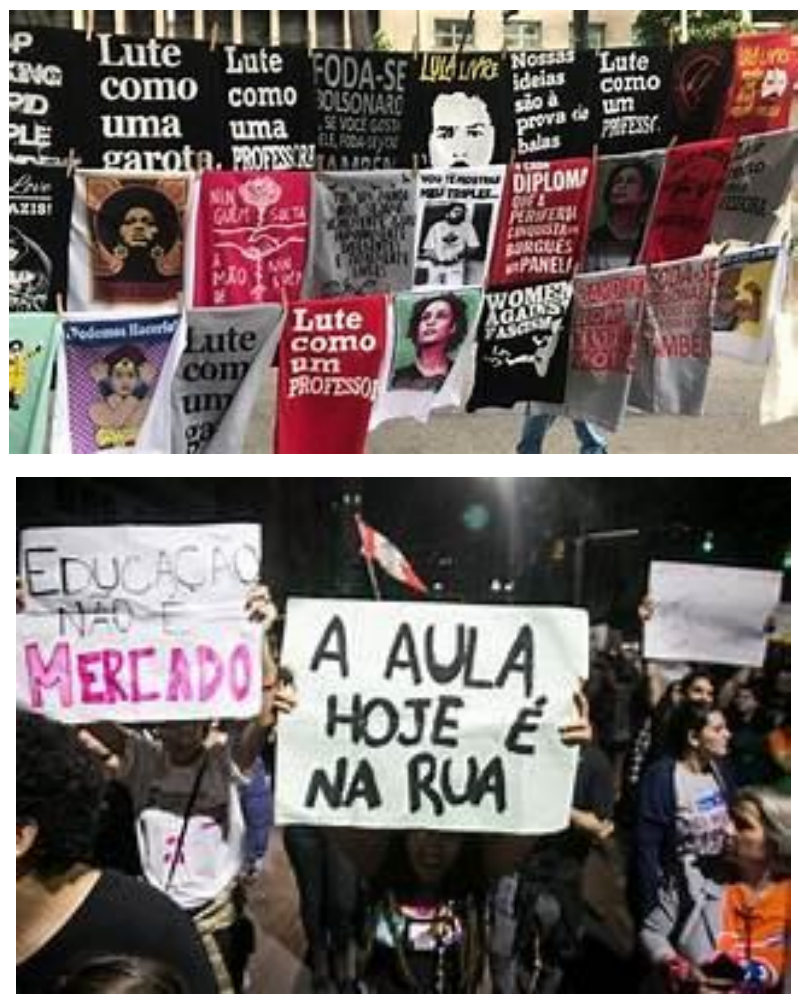

Fonte: https://veja.abril.com.br/politica/ao-vivo-estudantes-e-professores-protestam-contra-cortesna-educacao/

Os estudantes entraram com tudo reafirmando seu direito à educação pública:

Rev. Eletrônica Mestr. Educ. Ambient. Rio Grande, Dossiê temático "Imagens: resistências e criações cotidianas", p. 127-151, jun. 2020. E-ISSN 1517-1256 
Fotos: Manifestações de professores e estudantes contra cortes na educação
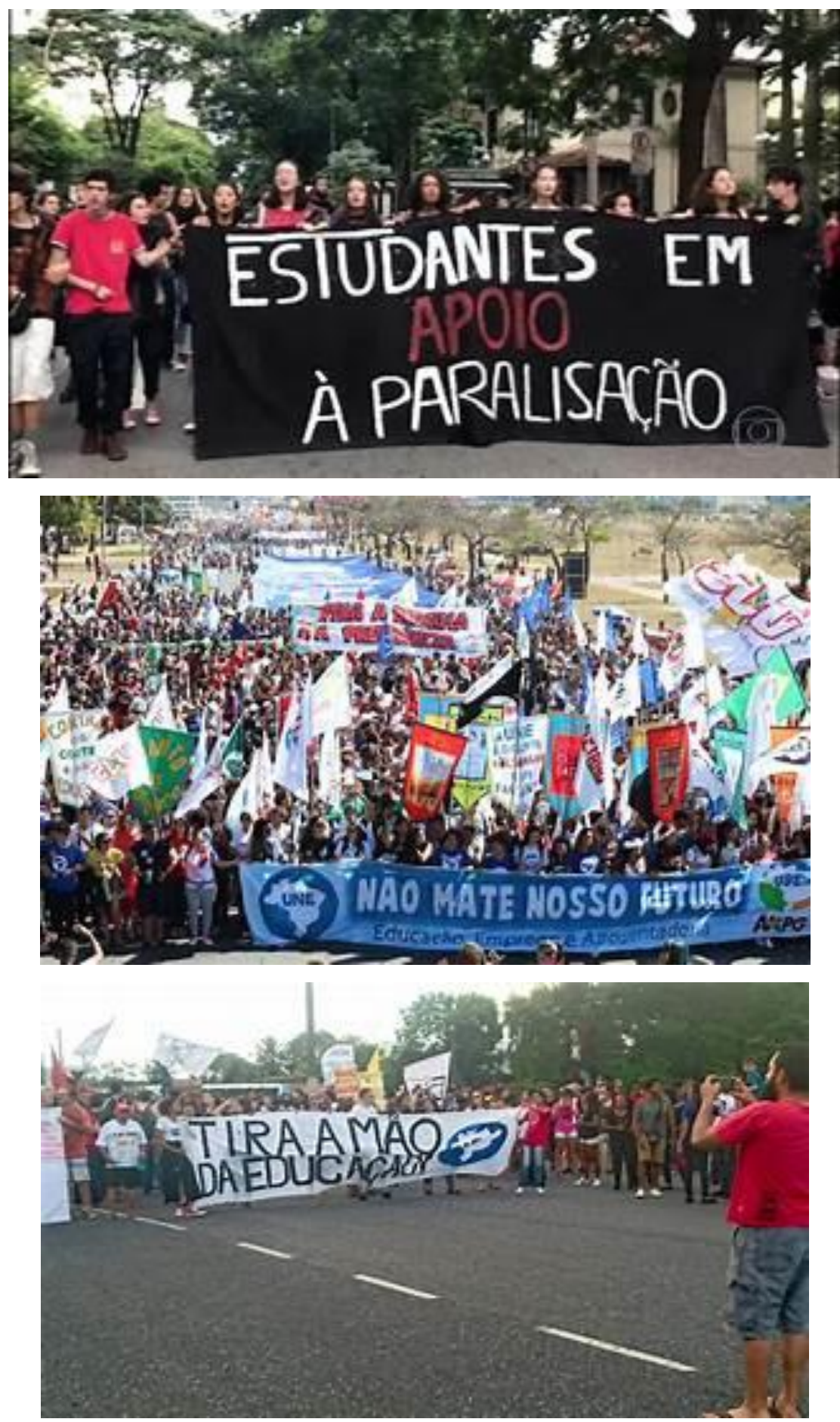

Fonte: https://veja.abril.com.br/politica/ao-vivo-estudantes-e-professores-protestam-contra-cortesna-educacao/

Daí a necessidade de nos armarmos contra a guerra já em curso.

Se "[...] a melhor maneira de descrever a situação contemporânea é falar do ‘triunfo' das forças capitalistas” (LAZZARATO, 2019, p. 99) - isto é, de seus absurdos, da

Rev. Eletrônica Mestr. Educ. Ambient. Rio Grande, Dossiê temático "Imagens: resistências e criações cotidianas", p. 127-151, jun. 2020. E-ISSN 1517-1256 
imposição naturalizante de suas imposições -, pois que nos atentemos justamente para a forma como esses "triunfos" se lançam sobre nós nas escolas. Conforme elucidou uma professora em seu momento de planejamento, não adianta continuarmos a comprar brigas com as famílias. "Elas já desconfiam de tudo que a gente faz, né? Eu tô tentando trazer elas para perto, sabe? Chamo para ir na sala, para fazermos um piquenique aqui dentro, para ensinar alguma coisa que eles sabem... Quero que as famílias tenham coisas boas para contar da gente também".

Se o que querem é nos ver perdendo forças, façamos alianças itinerantes; se nos tornaram inimigos públicos da sociedade, pois que encarnemos a figura de Robin Hood. Estamos em guerra. Não seremos meros personagens para os operadores de joystick da política ciborgue militar-empresarial.

\section{Professor: inimigo público nº 1 - aliado necessário}

Eduardo Galeano (2013) considerou que, para o mundo que emergia a partir da tomada de poder neoliberal, apenas uma escola do mundo avesso daria conta de instruir os modos de vida aptos a reconhecer o neoliberalismo como a forma de governo mais ideal para o nosso tempo. Debochando claramente das leituras neofascistas do darwinismo, Galeano destaca a perversão do conceito de lei do mais forte (ou sobrevivência do mais forte, como seria a tradução mais literal do conceito de Charles Darwin) em um modo de naturalização das desigualdades. À escola do mundo avesso, é claro, caberia ensinar o darwinismo da seleção natural (dos fortes, ricos, das empresas, dos acionistas) em detrimento daqueles reles trabalhadores que mendigam atenção fazendo dramas de suas dores.Operaria nessa escola, portanto, um aparato de culpabilização dos fracassos e de endeusamento dos sucessos.

No mundo avesso, aprenderíamos que nada há de mais natural que a sobrepujança de uns e a miséria de outros. Se antes a pobreza era "fruto da injustiça", agora "[...] a pobreza é o justo castigo que a ineficiência merece" (GALEANO, 2013, p. 32). E isso se aplica a tudo, todos e a quaisquer lugares. Afinal, se somos todos livres para produzir, conforme supõe a sociedade do desempenho (HAN, 2017), quem não produz não é senão por culpa de si próprio. Se a lógica atual é do yes, wecan!, bastaria aos corpos arcar com as consequências da própria liberdade.

A história do tempo presente seria, então, a história das escolhas dos corpos em se aplicarem às liberdades. Seríamos todos livres e, por conseguinte, tomaríamos as ações que 
nos fossem mais propícias para o nosso desenvolvimento.Nada exemplifica melhor o cúmulo das "conquistas" adquiridas pelo devido uso das liberdades que a repercussão memética da propaganda da EmpiricusResearch e a introdução de Betina Rudolph no ano de 2019.

De acordo com Betina - imagem viral e já quase personagem conceitual -, bastaram-lhe umas poucas restrições, guardar um pouco de sua renda, saber investir em compra de ações e, em menos de um ano, ela conseguiu seu um milhão de reais (CORREIO BRAZILIENSE, 2019).

Quaisquer usos da liberdade que não rendessem vitórias seriam, então, fracassos. A escola do mundo avesso seria essa que, desde a mais tenra idade, nos faria devotos de um desejo pervertido de liberdade e de autovalorização, de vitória e sobrepujança, de dominação e medo surreal do fracasso. Ela produziria em cada corpo o apreço pelas "escolhas próprias", tornando imperceptíveis as maquinações e agenciamentos que nutrem possibilidades para uns e deixam morrerem infinitas virtualidades para outros.

Vivemos a era de enaltecimento das conquistas e de culpabilização dos fracassos. À escola do mundo avesso caberia exatamente o fortalecimento dessa premissa: normalização das estratégias de submissão capital. Ou, conforme sugere Maurizio Lazzarato (2006, p. 52), “[...] as políticas neoliberais operam uma inversão das instituições de proteção em dispositivos de produção de insegurança", como expressa a fala da professora a seguir:

- Toda escola adora falar de cultura de paz, né? Este ano mesmo, já vi umas três professoras falarem disso, que temos que incentivar a cultura de paz. Mas que paz é essa, gente? Que paz é essa que faz as pessoas trabalharem até os 60-70? Que paz é essa que faz com que as mães tenham medo de deixar os filhos brincar na rua por causa de tiroteio da polícia? Que paz é essa que faz os políticos todos colocarem as pessoas contra professores? Paz é isso que eu uso para calar o outro?

Eis o perigo: na mão dos controladores hábeis de joystick, beiramos sempre o limite entre o desejo de produção de mundo e o de sua total destruição. Se não nos atentarmos às regras do jogo e ao objetivo maior da máquina de guerra do capital, acabamos sendo meros personagens orientados por players viciados em jogos pós-apocalípticos.

Conforme sugere o Comitê Invisível (2017), se hoje temos uma produção tão extensa de filmes, livros, séries e animes com cenários pós-apocalípticos, é por nos quererem crentes de que este mundo já acabou, de que já não há mais nada nele pelo qual valha a pena lutar. O cenário pós-apocalíptico não é o que virá para nos salvar. Ao 
contrário, é o que enfrentamos no agora das relações. O futuro é produzido no combate do tempo presente, imaginando não nossa derrota, mas nossas possibilidades de existência.

Então, trabalhar nas escolas é colocar-se no agora para ampliar as possibilidades de futuro. São infinitos presentes compossíveis em uma escola, em uma sala de aula. E os tempos todos se cruzam. Ali, onde professoras e professores fazem os currículos se desdobrarem aos infinitos da ampliação das redes de afetos (CARVALHO, 2009), os tempos e os afetos se confundem. Aumenta-se o grau de afeto para que as percepções e as atuações no tempo se intensifiquem. Ou seria o contrário?

- No início do ano, a Secretaria queria tirar a biblioteca, a sala de vídeo e o refeitório aqui da escola, por causa do projeto da Prefeitura. A gente ia perder tudo isso assim, do nada. Ninguém avisou a gente no ano passado. Quem nos falou foi a bibliotecária. Ela é um amor, uma das pessoas mais politizadas daqui. Mas isso não era papel da direção? Aí a gente fez um documento para a Secretaria, uma carta de repúdio. Quando falamos com as crianças, três turmas começaram a fazer cartazes, placas, cartinhas... Teve um monte de coisa ótima! "NÃO TIREM NOSSA BIBLIOTECA!", "A SALA DE VÍDEO É NOSSA!", "ONDE NÓS VAMOS COMER?”, "A GENTE SÓ PODE FICAR NA SALA?”. Um monte de coisa ótima! E sabe o pior? A diretora não queria entregar! Ela agiu com neutralidade, mas depois ficamos sabendo que ela ligou para lá e disse que iria dar problema. Mas ela não estava do nosso lado; estava do deles!

Por tal motivo, somos a um só tempo feitos técnicos do desenvolvimento nacional (personagens do jogo apocalíptico da máquina de guerra capitalística) e tomados como inimigos públicos de alto calibre.

Se se aceita a premissa de que a escola é também atravessada por uma tendência apocalíptica (a escola do mundo avesso do Galeano pode ser encontrada em cada esquina), também é preciso que enxerguemos as organizações políticas das escolas entre os corpos que, de algum modo, resistem.

Ou nos colocamos a trabalho da máquina de guerra que assegura e legitima as desigualdades e a destruição do mundo ou nos tornamos seus inimigos públicos:

- Eu fico de cara com umas coisas que a gente ouve no rádio, sabe? Eu acordo todo dia 4h20min da manhã, tomo meu banho, pego minhas coisas, ligo o carro e venho. Aí ligo o rádio para ficar mais desperta e sabe o que eu ouvi hoje? Que a gente trabalha pouco perto das outras categorias, porque nosso serviço pode ser todo realizado em um só turno! - Gente, só faltou falar que a gente ganha muito!

- Eu não sei se falou, eu mudei de rádio na hora!

- Lembra aquele menino que me perguntou ano passado se eu trabalhava ou se eu "só" dava aula?

Rev. Eletrônica Mestr. Educ. Ambient. Rio Grande, Dossiê temático "Imagens: resistências e criações cotidianas", p. 127-151, jun. 2020. E-ISSN 1517-1256 
- Eu lembro! "Você trabalha ou só dá aula, tia?”. Pelo menos quando é a criança a gente ainda ri!

Em uma estratégia quase global de diminuição da figura docente, vemos crescerem não apenas os insultos advindos de figuras políticas como também a multiplicação de imagens de docências enfraquecidas veiculadas por notícias "desinteressadas", como a comentada pela professora.

A bem da verdade, o esquema de notícias "desinteressadas" funciona como um prelúdio de morte às docências. De acordo com o Folha de São Paulo (2019), há um número quase excessivo de professores formados no país e um número tão grande quanto de professores em formação. Segundo a lógica do jornal, não há ou haverá crianças o suficiente para o número de professores no Brasil. A matéria - em sua tentativa de neutralidade - deixa evidente que as escolas públicas ou particulares não necessitam mais de professores, não há mais necessidade de tanto esforço para continuarmos a nos fazer professoras e professores em escolas. Com o tempo, estaremos extintos.

Tornamo-nos um risco do mais alto grau à política vigente.

Michel Foucault (2010), ao falar da transição das guerras contra todos para as guerras internas (chamadas guerras civis), pontuava que um dos modos de operação das práticas de governamento jaz justamente em fazer com que as populações se percebam em um risco contínuo. Antonio Negri e Michael Hardt (2016) elevam o risco ao afirmarem que todo corpo, no funcionamento capitalístico, está amarrado a quatro pilares da dominação: o endividamento proveniente da era do consumo forçado; a mediatização diante da multiplicação sem fim das tecnologias de informação; a securitização ideal e inalcançável por medo de tudo e de todos; a representação política que, cada vez mais, enfraquece a crença de que há política fora do circo de governanças. Em suma, é preciso que os corpos se endividem, prendam-se às telas, clamem por segurança e depositem suas esperanças no outro para que as insurreições não surjam.

O problema, sugere-nos o grupo Centelha (2019), é que as juventudes fazem os movimentos insurrecionais explodirem. As ruas queimaram em 2013, os estádios da Fifa quase foram derrubados em 2014, as escolas foram ocupadas em 2016, as ruas foram invadidas em 2019. Em cada momento, em maioria, as juventudes expuseram seus corpos. “A juventude aprendeu a não esperar nada [...]. Ela é a primeira manifestação do ingovernável e, em mais de uma ocasião, fez as ruas queimarem" (CENTELHA, 2019, p. 72).

Rev. Eletrônica Mestr. Educ. Ambient. Rio Grande, Dossiê temático "Imagens: resistências e criações cotidianas", p. 127-151, jun. 2020. E-ISSN 1517-1256 
Não para menos, o ataque do presidente às juventudes precisa ser uma ofensa às juventudes, mas tirando delas a verdadeira "culpa". É preciso que outro personagem apareça como bode expiatório. Afinal, um país sem a força da juventude seria apenas uma memória e já o fiasco de uma vida.

Os próximos da mira, por efeito, fomos nós, professoras e professores.

Os famosos doutrinadores.

- Sabe que aqui, na escola, a gente tem que tomar cuidado com o que fala perto de certa pessoa, né?

- Quem?

- Aquela colega...

- A bolsonarista? Eu hein! Tô nem aí para ela! Esses dias ela me perguntou para que eu estava ensinando História da África para meus alunos: "Isso não é matéria de segundo ano não, é?". Cheia de dedos para me acusar de alguma coisa!

- Ué, História da África não tem a ver com TODO o planeta?

- Não é? Berço da humanidade, com biomas parecidos com os nossos... Minhas crianças todas já sabem que um monte de animal nosso é parente de animais de lá! Já até sabem diferenciar a onça-pintada, o leopardo e o guepardo!

- Quero ver o que ela vai falar com os alunos dela quando começarem a perguntar sobre cor da pele, etnia...

- Tenho medo!

Voltemos um pouco, pois, à história de nosso país.

Galaeano (2013) observou que, para que a escola do mundo avesso funcionasse, seria necessário incutir nas novas gerações o devido medo perante todas as forças revolucionárias. Destacou que, após a revolução cubana, as forças armadas latinoamericanas " $[\ldots]$ passaram a se ocupar do inimigo interno, porque assim o exigia a defesa do mundo livre e da ordem democrática" (GALEANO, 2013, p. 82).

Seguindo o mesmo rastro da ampliação dos inimigos internos, o grupo Centelha propõe que, desde 1935, quando Getúlio Vargas assinou a Lei nº. 38, de 4 de abril de 1935 (Lei de Segurança Nacional) (BRASIL, 1935), as definições de "inimigo interno" vêm apenas se expandindo. Se antes o inimigo era aquele que criava "instalações clandestinas de rádio" para fazer ataques ao governo, em 1964, a ameaça comunista e sindicalista rendeu munições incontáveis. Quaisquer corpos cabiam dentro da ameaça comunista: “[...] desempregados, miseráveis, negros, periféricos; feministas, LGBT's e intelectuais; padres, putas e artistas" (CENTELHA, 2019, p. 45-46). Na virada do decênio de 2020, vemos hoje a atualização do risco que brota das juventudes, das periferias, das negritudes, das feministas, das sexualidades dissidentes e dos desempregados.

Rev. Eletrônica Mestr. Educ. Ambient. Rio Grande, Dossiê temático "Imagens: resistências e criações cotidianas", p. 127-151, jun. 2020. E-ISSN 1517-1256 
O medo não deriva mais do além-mar. Está em todo lugar. O medo foi a tal ponto radicalizado que não sabemos se sentimos medo por nós mesmos ou se é o outro que deveria nos temer.

Nesse desenrolar da História, o professor foi tornado um terrorista latente. Daí a liberdade, no discurso político, de que nos exponham sem medo. Não apenas a deputada do PSL, mas também a ministra Damares Alves, fizeram circular a ideia de que todos os professores devem ser vigiados de perto e expostos a qualquer situação:

É a caça ao terrorista globalizada. Se outrora a contrainsurreição precisava da simpatia da população, o contraterrorismo dispensa a dimensão política e se resume ao plano policial-securitário. Guerra infinita, guerra sem baixas (do lado dos que possuem a tecnologia), mas também guerra sem vitória, guerra perpétua, guerra sem sacrifício, guerra da autopreservação absoluta (PELBART, 2019, p. 93).

De acordo com o discurso bolsonarista, fomos nós, professoras e professores, que atualizamos os corpos da população e da juventude em suas forças insurrecionais. Tendemos a desconsiderar essa afirmação estapafúrdia. Rimos dela continuamente, na verdade. Todavia, talvez devêssemos começar a reconhecer nossos potenciais ares insurrecionais. Ridicularizamos a ideia de doutrinadores pelo simples fato de não conseguirmos sequer fazer com que os alunos cumpram as atividades ditas pedagógicas. Todavia, talvez seja por esses conhecimentos parecerem insuficientemente políticos a eles; talvez seja por se preocuparem com a situação do agora em que vivemos.

Podemos não ter dado início a nenhuma insurreição, mas angariamos aliados para as lutas que não são somente nossas. Nesse caso, a máquina de guerra capitalista foi parcialmente vencida com o retorno das verbas retidas: um possível por um afeto e afecção da educação pública como máquina de guerra insurrecional.

\section{Notas para um embate em curso: afetar-se com o mundo, produzir o comum}

Para cada imagem atual que retiramos do mundo, surge, no intervalo afetivo, o seu duplo coalescente, indissociável e especular como uma imagem-virtual. O atual é sempre presente, mas porque é presente, sempre muda, sempre passa, sendo substituído instantaneamente por outro presente. Assim, cada momento tem sua face atual como percepção e sua face virtual como lembrança. A memória passa a ser tomada, então, como 
um imenso reservatório virtual a ser atualizado conforme os encontros convocados por meio de cada novo presente. É aí, então, que surge a imagem-tempo e, enfim, a imagem do pensamento (DELEUZE, 1990) potencializada por meio da atmosfera cristalina e onírica em que as imagens nos mergulham, pois, nessa atmosfera, os objetos e os meios conquistam uma realidade material autônoma que os faz valerem por si mesmos, produzindo pontos de indiscernibilidade entre o real e o imaginário, o sujeito e o objeto, o passado e o presente, o atual e o virtual.

Esse tempo puro desconhece a hierarquia cronológica ou o julgamento da importância de cada acontecimento. Não sabemos qual é o processo que faz aparecer uma imagem virtual em detrimento de outra, ou que reúne, numa mesma imagem, acontecimentos de tempos cronológicos absolutamente distintos (DELEUZE, 1990).

Assim, podemos encontrar o pensamento no cotidiano. Nessa perspectiva, não é mais o esquema sensório-motor que é convocado e, sim, a vidência, pois o acontecimento passa a ser uma situação ótica e sonora pura, investida pelos sentidos, uma descrição físico-geométrica e inorgânica que se faz por meio de uma imagem atual. No entanto, em vez de se prolongar em movimento, conjuga-se com imagens-virtuais formando um circuito independente do esquema sensório-motor.

Um momento qualquer dá a pensar a qualquer um: “[...] é todo o real, a vida inteira que se tornou espetáculo" (DELEUZE, 1990, p. 105). Retoma-se, então, o cotidiano em toda a sua potência, visto que a imagem potencializa o pôr em comum o que é comum, colocar para circular o que já é patrimônio de todos, fazer proliferar o que está em todos e por toda parte, seja a linguagem, seja a vida, seja a inventividade, seja a insurreição.

Segundo Pelbart (2013, p. 3), vivemos hoje uma crise do "comum". Para o autor,perambulamos em meio a espectros do comum: a mídia, a política, os consensos econômicos consagrados, os fundamentalismos étnicos ou religiosos, a invocação civilizatória calcada no medo, a militarização da existência para defender a "vida" supostamente "comum" ou, mais precisamente, para defender uma forma de vida dita “comum”. "No entanto, sabemos bem que essa 'vida' ou 'forma de vida' não é realmente 'comum"' (p. 3).

Se, de fato, há hoje um sequestro do comum, uma expropriação do comum, ou umamanipulação do comum, sob formas consensuais, unitárias, espetacularizadas,totalizadas, transcendentalizadas, é preciso reconhecer que, ao mesmo tempo eparadoxalmente, tais figurações do "comum" começam a aparecer finalmente naquiloque são, puro espectro.É isso, justamente, que tanto temem de nós nas escolas. 
Não existe um comum que possa ser referido simplesmente a elementos orgânicos ou a elementos identitários. O comum é sempre construído por um reconhecimento do outro, por uma relação com o outro, com o mundo, que se desenvolve nessa realidade. Os cotidianos escolares são precisamente a intensificação desses contatos, das ampliações das realidades - ainda que nada tenham a ver com a tecnologia da realidade expandida tão ensejada pelo capital.

É nas escolas - nas escolas públicas, principalmente - que encontramos as mais infinitas possibilidades de existência que, em contato com outras, aprendem a produzir redes de comum entre elas. Às vezes chamamos essa realidade de multidão, porque, quando se fala de multidão, de fato, se fala de toda uma série de elementos de (re)existência que objetivamente estão ali e que constituem o comum. Mas o problema não é simplesmente ser comum ou ser multidão; o problema é fazer multidão, construir multidão, construir comum, construir comumente, no comum, fazer a educação pública proliferar as possibilidades de existência e resistências (CARVALHO, 2015).

\section{Referências}

BERGSON, Henri. Matéria e memória: ensaio sobre a relação do corpo com o espírito. Tradução de Paulo Neves. São Paulo: Martins Fontes, 2006.

BRASIL. Lei $n^{\mathbf{0}} 38$, de 4 de abril de 1935. Define crimes contra a ordem política e social. Presidência da República. 1935. Disponível em: https://www2.camara.leg.br/legin/fed/lei/1930-1939/lei-38-4-abril-1935-397878republicacao-77367-pl.html. Acesso em: 20 jan. 2020.

BRUM, Eliane. Como resistir em tempos brutos. Disponível em: https://brasil.elpais.com.br/2018/10/08/opinion/1539019640_653931.html. Acesso em: 11 fev. 2020.

CARVALHO, Janete Magalhães. A escola como comunidade de afetos. Rio de Janeiro: DP et al., 2009.

CARVALHO, Janete Magalhães. O "comunismo do desejo" no currículo. In: FERRAÇO, Carlos Eduardo et alii. Diferentes perspectivas de currículo na atualidade. Petrópolis/RJ: De Petrus, 2015. p. 79-98.

CENTELHA. Ruptura. São Paulo: n-1 Edições, 2019.

COMITÊ INVISÍVEL. Motim e destruição agora. Tradução de Vinicius Honesko. São Paulo: n-1 Edições, 2017. 
CORREIO BRAZILIENSE. Entenda a polêmica de Betina, a jovem milionária que virou meme nas redes. Publicado em 15 mar. 2019. Disponível em:

https://www.correiobraziliense.com.br/app/noticia/tecnologia/2019/03/15/interna_tecnolog ia,743335/entenda-a-polemica-de-bettina-a-jovem-milionario-que-virou-meme-nasr.shtml. Acesso em: 17 jan. 2020.

DELEUZE, Gilles. A imagem-tempo. Tradução de Eloísa de Araújo Ribeiro. São Paulo: Brasiliense, 1990.

DELEUZE, Gilles. Micropolítica e segmentaridade. Tradução de Suely Rolnik. In: DELEUZE, Gilles; GUATTARI, Félix. Mil platôs: capitalismo e esquizofrenia. São Paulo: Editora 34, 1996. v. 3.

DELEUZE, Gilles. Tratado de nomadologia: a máquina de guerra. Tradução de Peter PálPelbart. In: DELEUZE, Gilles; GUATTARI, Félix. Mil platôs: capitalismo e esquizofrenia. São Paulo: Editora 34, 1997. v. 5.

FANON, Frantz. Oeuvres. Paris: La Decouverte, 2011.

FOLHA DE SÃO PAULO. Brasil corre risco de ter professores em excesso e sem emprego nos próximos anos. 5 dez. 2019. Disponível em:

https://www1.folha.uol.com.br/educacao/2019/12/brasil-corre-risco-de-ter-exercito-deprofessores-sem-emprego-nos-proximos-anos.shtml. Acesso em: 20 jan. 2020.

FOUCAULT, Michel. História da sexualidade 3: o cuidado de si. Tradução de Maria Thereza da Costa Albuquerque. São Paulo/SP: Graal, 1985.

FOUCAULT, Michel. Em defesa da sociedade: curso no Collège de France (1975-1976). Tradução de Maria Ermantina Galvão. São Paulo: Editora WMF Martins Fontes, 2010.

GALEANO, Eduardo. De pernas pro ar: a escola do mundo avesso. Tradução de Sérgio Franco. Porto Alegre: L\&PM Pocket, 2013.

G1. Deputada estadual do PSL eleita por SC incita alunos a filmar e denunciar professores. 29 out. 2018. Disponível em: https://g1.globo.com/sc/santacatarina/eleicoes/2018/noticia/2018/10/29/deputada-estadual-do-psl-eleita-por-sc-incitaalunos-a-filmar-e-denunciar-professores.ghtml. Acesso em: 13 jan. 2020.

HAN, Byung-chul. Sociedade do cansaço. Tradução deEnio Paulo Gianchini. Petrópolis: Vozes, 2017.

LAZZARATO, Maurizio. As revoluções do capitalismo. Tradução de LeonoraCorsini. Rio de Janeiro: Civilização Brasileira, 2006.

LAZZARATO, Maurizio. Signos, máquinas, subjetividades. Tradução de Paulo Domenech Oneto e Hortência Lencastre. São Paulo: n-1 Edições, 2014.

LAZZARATO, Maurizio. Fascismo ou revolução? O neoliberalismo em chave estratégica. Tradução de TakashiWakamatsu e Fernando Scheibe. São Paulo: n-1 Edições, 2019.

Rev. Eletrônica Mestr. Educ. Ambient. Rio Grande, Dossiê temático "Imagens: resistências e criações cotidianas", p. 127-151, jun. 2020. E-ISSN 1517-1256 
NEGRI, Antonio; HARDT, Michael. Declaração: isto não é um manifesto. Tradução de Carlos Szlack. 2. ed. São Paulo: n-1 Edições, 2016.

PELBART, Peter Pál. Elementos para uma cartografia da grupalidade. Disponível em: http://www.itaucultural.org.br/proximoato/pdf/textos/ textopeterpebart.pdf. Acesso em: 2 dez. 2013.

PELBART, Peter Pál. Ensaios do assombro. São Paulo: n-1 Edições, 2019.

REALI, Noeli Gemelli. A desobediência do menor: rotas de fuga do cinema infantil. 2017. Tese. (Doutorado em Educação) - Universidade Federal de Santa Catarina, Centro de Ciências da Educação, Programa de Pós-Graduação em Educação, Florianópolis/ SC, 2017.

SAMAIN, Etienne (org.). Como pensam as imagens. Campinas: Editora da Unicamp, 2012.

SARTRE, Jean Paul. Situações V: colonialismo e neocolonialismo. Tradução de Cristina Prado. Rio de Janeiro: Tempo Brasileiro, 1968.

Submetido em: 08-03-2020.

Publicado em: 01-07-2020.

Rev. Eletrônica Mestr. Educ. Ambient. Rio Grande, Dossiê temático "Imagens: resistências e criações cotidianas", p. 127-151, jun. 2020. E-ISSN 1517-1256 